\title{
A Spatial Sustainable Development Model Based on Partnership between Government, Community and Specialist in Baghdad
}

\author{
Mukdad A. Al-Khateeb1, Nadhir Al-Ansari², Sven Knutsson² \\ ${ }^{1}$ University of Technology, Baghdad, Iraq \\ ${ }^{2}$ Luleå University of Technology, Luleå, Sweden \\ Email:mukdadalkhateeb@yahoo.com,nadhir.alansari@ltu.se,sven.knutsson@ltu.se
}

Received 14 July 2016; accepted 21 August 2016; published 24 August 2016

Copyright @ 2016 by authors and Scientific Research Publishing Inc.

This work is licensed under the Creative Commons Attribution International License (CC BY). http://creativecommons.org/licenses/by/4.0/

c) (i) Open Access

\begin{abstract}
Iraq is facing fatal challenges: internal, external and natural that are threatening the well-being of the Iraqi community at present and certainly jeopardizing the sustainable development at all levels of Sustainable Development (SD)-Capitals: natural, human and social, and manufactured/financial. This paper is intended to discuss on establishing a Sustainable Neighborhood in Baghdad, where it could serve as an experimental project to test the forms of expenditure that would guarantee the best eco-efficient transformation of expenditure to Sustainable Development Goals (SDGs). The paper illustrates the challenges of SD and the factors that would exacerbate their effect unless dealing with through scientific-well managed procedures based on green growth policies and sustainable development strategies.
\end{abstract}

\section{Keywords}

Challenges of Sustainable Development in Iraq, Investment for Sustainable Development, Sustainable Development Capitals, Sustainable Communities, Sustainable Neighborhood, Triple Partnership

\section{Introduction}

Sustainable Development (SD) defined in 1987 by Brundtland Report as "the development that meets the needs of the present generations without compromising the ability of future generations to meet their own needs" (UN, 1987), seeks social happiness based on eco-efficient economy. Throughout the age of SD, the human element has always been its core interest, targeted by the MDGs, being one of the three SD-Capitals, and deeply consi- 
dered during discussions and workshops for the post-2015 SDGs (ESCWA, 2013a).

It seems that the three pillars of SD: Environment, Community and Economy are becoming insufficient to secure this kind of development. Some argue that "Good Governance" (UN, 2013a) should be added as the fourth, and others believe that "Peace" (Brundtland, 1987) is essential to secure the development and ensure its sustainability. In every case, this debate is expected to ever last as it reflects the vitality and practicality of SD and the need to continually develop new models of development that coincide with the main goals, objectives and continuously developing concepts of SD, community inclusive and taking into consideration the prevailing circumstances (Allen \& Slotterback, 2011).

In general, the MENA region is witnessing rather difficult stage. The community of the region is generally suffering high levels of desperation as a direct result of the ongoing political disturbances and frequent associated violence. The internally displaced persons (IDP) and seekers for immigration to other countries are dramatically escalating (Mikail, 2013). Internal wars and armed conflicts are overshadowing the area and worst of all, the dominance of destructive mentalities (in power and authorities) that are encouraging exclusion, segregation and racialism that have driven the affected social groups and communities to extremism and fanaticism (Wehrey, 2014).

Iraq, historically named "Mesopotamia", although known to have had witnessed the ever first landmarks of $\mathrm{SD}$ in the human civilization, is currently facing great challenges that are increasingly threatening the lives of the Iraqis. The diverse yet fierce challenges: external, internal and natural have resulted to a comprehensive deterioration that demands on establishing a Sustainable Neighborhood (SN), a new approach for a solution that would, in addition to solving the ongoing living difficulties at a spatial level (district or part of it), serve as a luster of hope for the community, on-site learning opportunity for learners at all levels, a research laboratory for professionals and experts, and a success story for the decision-makers and public services' departments.

The proposal of establishing a Sustainable Neighborhood (SN) in Baghdad was presented (by the Author) during a key activity of a conference on "Environment and Sustainable Development" held at the Environment Research Center-University of Technology (ERC-UoT), Baghdad-Iraq in 29-30 December 2013 (University of Technology Environmental Research Center, 2013). Realizing the importance of gathering as many partners as possible, and considering the effectiveness of the decision makers in initializing the project, six external visitors (high ranking officials), were invited for a dialogue on the project as High Level Discussion Panel (HLDP). They represented Media, Academia, Ministry of Planning, Ministry of Environment, Ministry of Housing and Construction, and the Municipality of Baghdad. The results of the discussions seemed to be so encouraging and with the help and support of the audience, a decision was made to convene a Working Group composed of the HLDP and other related partners to further discuss and evaluate the SN proposal.

The structure of the SN varies according to the prevailing conditions and the challenges as related to the basic SD-capitals: natural, human and social, and also may be a mirror for the institutional framework performance. Many international models for such neighborhoods are available; some seek the inclusion of foreigner immigrants into their community (Allen, 2013) while others are mainly concerned with environmental issues.

\section{Method}

Illustrating the different challenges of sustainable development in Iraq, and showcasing the factors that would worsen their affect unless dealt with by the partnership of; community, public services and the specialists through a "Sustainable Neighborhood", which is a hypothetical spatial model intended to explore the efficient pathways in eliminating/minimizing the effect of the prevailing devastating conditions which are becoming the main reason for despair and misery of the Iraqi community.

\section{Challenges of SD in Iraq}

Iraq, a West Asia-Middle East country, is the legitimate inheritor of the ancient "Mesopotamia"; a Greek name for the land between the rivers, with an age correlated to the earliest evidence of human culture since 5000B.C (Dictionary.com, 2014). Iraq's successive cultures have efficiently contributed to the world's civilization, but also inherited successive generations of diverse human races that resulted in a magnificent social mosaic (Al-Khateeb, 2010), unfortunately cracked after the 2003 invasion. Presently, Iraq is facing severe challenges; internal, external and natural that are expected to exacerbate in the near future unless confronted properly at all levels; governmental and societal. 
At the end of 2013, the return to violence has resulted to huge numbers of new refugees, sectarian and ethnic polarization that raised serious fears of a civil war (Cordesman and Khazai, 2014). that demands a parallel wise peace action plan to dominate peace based upon eco-efficient economy.

\subsection{Socio-Economic Challenges}

Iraq is in a serious crisis bordering a civil war as a result of the accumulated mistakes made by the US after the invasion in 2003. Their failure in establishing a workable political system and effective governance throughout their direct authority has resulted in a deeply divided nation into sectarian and ethnic groups that are becoming more violent and divided since US left Iraq at the end of 2011 (Cordesman and Khazai, 2014).

Iraq produced oil at a rate of 3.5 million bpd in February 2014, and exported at a rate of 2.8 million bpd (Al-Monitor, 2014). It has around 143 Billion Barrels of crude oil to become the fifth largest oil reserve in the world and OPEC's second largest producer of crude oil. Iraq is the world's sixth net exporter of petroleum liquids at the end of 2012. In 2010, Iraq was the fourth largest natural gas flaring country, and the majority of Iraqi natural gas production is still being flared (Beta, 2014).

Iraq's economy is failing to maintain adequate employment growth and suitable living standards, even when the proportion of Iraqis with incomes less than 2.5 US\$ per day has inclined from $13.9 \%$ to $11.5 \%$ and the Gross Domestic Product per capita has risen from $0.8 \%$ to $2.1 \%$ during 2007 to 2011 . Also, there is a distinct gap between the very wealthy people and those living below the survival level. A large portion of the Iraqis is caught in poverty accompanying food insecurity and limited access to basic services, with a real shortage of working opportunities (especially for young people) and a low participation of women in the labor market (UNDP, 2015). Iraq's revenues in 2013 amounted to IQD 119.3 Trillion, 93\% of which is from oil, which makes of it a unilateral economy with full dependence on a consumable resource (Joint Analysis Policy Unit-JAPU, 2013).

The revenues in 2010 were estimated to be around 52.8 Billion USD and Iraq was ranked 44 amongst the highest revenues' country in the world (Natural Resource Governance Institute, 2015) and in 2011 escalated to USD 72.4 Billion enlisting Iraq internationally as the 38th highest income country (WHO, 2011), but still the unemployment rates among the youth population (15 - 24 years) only dropped from $30 \%$ to $22.8 \%$ from 2008 to 2011. Despite the high revenues gained from the Oil, estimated at 2011 to be around 67 billion USD, the national expenditure was 85 billion USD, $73 \%$ of which cover the running cost (mainly salaries) and only $27 \%$ dedicated for investment (Al-Anbagy et al., 2011). Only 40\% of all those in regular work are employed by the government and public sector, while the remainder is employed mainly in the informal and others in the private sectors (UNDP, 2015). It is unfortunate that Iraq was ranked as the 4th highest corrupt country by Transparency International in 2010 (Transparency International, 2011) and again ranked 178 out of 182 countries in 201,122.

Regarding food insecurity, the population consuming less than the recommended daily energy intake recorded a reduction of only $1 \%$. Although the current national rate is $6 \%$, Basrah province has a high rate of $21 \%$, whereas the percentage of underweight under five years children decreased from $15.9 \%$ in 2000 to $8.4 \%$ in 2011 . Still, some provinces are facing high rates of food deprivation, with Anbar, Baghdad and Najaf having the highest malnutrition rates in the country 15 .

Every three women, aged $15-29$, have at least one unemployed. It is increasingly important to stimulate Iraq's economy and create new employment opportunities as $39 \%$ of the Iraqi population are under the age of 15 , and the number of young Iraqis entering the labor force is growing. From an economic and financial perspective, the size of Iraq's oil revenues could slow down efforts to branch out the economy. Oil export revenues have led to a better exchange rate. But, usually stronger currency has a negative impact on other (non-oil) industries, by making domestic products less competitive compared to imported products and consequently drop in exports and rise in imports, and also by rising production costs for non-traded sectors (IAU, UN, 2012).

The second largest contributor to GDP in Iraq, after the oil sector, is still the (Agriculture), which is the main cause of rural employment and livelihoods for poor and food insecure people, has declined over the years from $9 \%$ of the GDP in 2002 to only $3.6 \%$ in 2009. The net agricultural exports was USD 78 million in 1985, then dropped to USD 68 million by 2008. Until 1996, Iraq cultivated more date palms than any other country in the world. Total date production ranged between 500,000 and 600,000 tons/year. After a considerable decrease, exports are now improving, but production is still only 200,000 - 300,000 tons/year (UN-Iraq, 2013). According to FAO (2010), food security be present when all people, at all times, have physical, social, and economic access to adequate, safe, and healthful food that meets their nutritional needs and food preferences for an active and 
healthy life while $5.7 \%$ of the Iraqi population ( 1.9 million) are food deprived, consuming less than the average dietary energy requirements of 2161 kilocalories per day, and another 4 million Iraqis or 14\% of the population are vulnerable to food (Relief Web, 2012).

\subsection{Challenges of Environmental Sustainability}

The Tigris and Euphrates Rivers cover an area of $126,900 \mathrm{~km}^{2}$ and $177,600 \mathrm{~km}^{2}$ respectively, and are the primary sources of surface water in Iraq, resulting in moderate water availability estimated at $2400 \mathrm{~m}^{3}$ per person/year. With the exception of Turkey, Iraqis have more water than any of its their neighboring countries (Al-Ansari and Knutsson, 2011; Al-Ansari, 2013; Al-Ansari et al., 2014 \& 2015; ESCWA, 2013b), but unfortunately the levels of surface water in the reservoirs, lakes and rivers are diminishing to critical levels as a result of the poor management of water resources. This also applies to groundwater aquifers; their recharge has impacted to the level and quality of groundwater supplies. Tigris and Euphrates are suffering fallen discharge rates and are already declining to less than a third of their usual capacity and predicted to drop further in coming years (IAU, UN, 2012; UN, 2013a). Drinking and irrigation water quality is poor and violates both Iraqi National Standards and the World Health Organization guidelines. The Biochemical Oxygen Demand (BOD); pointing out the degree of water pollution by organic material, was found to be $36.2 \mathrm{mg} / \mathrm{L}$ in 2010 , more than thrice the national limit of $10 \mathrm{mg} / \mathrm{L}$, signifying a disturbing increase in water pollution (UN, 2013b).

The Total Dissolved Salts (TDS) in the Euphrates river water amplified from $457 \mathrm{ppm}$ in the 1980s to 1200 ppm in 2009 reflecting a quick deterioration of inward water. As reported by IOM in 2012; the high pollution and salinity levels had destructive effects on livestock, agriculture, and fishing in the Muthanna, Missan Basra, and Wassit governorates (UN, 2013b). According to the Environment Performance Index (EPI), Iraq was ranked in 2005; 143 out of 146 countries, in 2008; 150 out of 163, in 2010; 150 out of 163 while in 2012, when the EPI objectives of environmental policy were based on; environmental public health \& ecosystem vitality and took into consideration the environmental health, water (effects on human health), air pollution (effects on human health), air pollution (ecosystem effects), water resources (ecosystem effects), biodiversity and habitat, forests, fisheries, agriculture and climate change \& energy, Iraq came the last amongst the countries encountered in the assessment to become $132 / 132$ (Environmental Performance Index, 2005, 2008, 2010, 2014).

As announced by the Government of Iraq, $92 \%$ of Iraq's area is at the risk of desertification (JAPU, 2014). It is expected that the next 10 years will witness frequent dust-storms, with potentially hurtful effects on Iraq's agriculture and food security. Dust-storms damage crops, cause soil loss and remove the organic matter and nutrient rich topsoil particles, thereby reducing agricultural productivity (UN, 2013c). The erosion of one centimeter of surface soil is anticipated to reduce the agricultural crop production by more than $2 \%$ (UN-Iraq, 2013). UNEP, FAO, and the UN's Priority Working Group on Environment are supporting the National Program to Combat Sand and Dust-Storms in Iraq. In 2012, the Prime Minister set up a high level national commission to coordinate and advance efforts to combat sand and dust-storms (UN-Iraq, 2013).

Until Feb 2013, the Ministry of Environment documented 122 dust-storms and 283 dusty days and suggested that within the next ten years, Iraq might witness 300 dust-storms per year. These projections emphasize the vital need for a concerted regional effort to tackle the phenomenon today. Iraq faces an exceptional set of environmental challenges and considered as one of the region's most exposed countries to climate change. Rising environmental degradation and rising frequency and intensity of acute weather events, especially Sand and Dust Storms (SDS), take a massive burden on socio-economic life and human development across the region. It has been recognized that climate change and environmental degradation go beyond boundaries and that they can't be addressed efficiently through national level interventions alone. While many challenges persist, regional governments acknowledged that addressing environmental issues, such as SDS, is also an opportunity for enhanced cooperation and for making a substantial difference to regional populations and economies (UN, 2013c).

\section{Prospects Based on Current Challenges}

Iraq is a state under severe demographic strain from population growth and from an economy that has failed to translate oil wealth into economic growth, significant levels of employment, and sufficient per capita incomes 12 .

Food security is a serious threat to the Iraqis as with an annual population growth rate of $3 \%$, the inhabitants of Iraq are expected to exceed 42 million by 2020. To maintain the average supply levels of 1998-2008 (213 $\mathrm{kg} /$ per year/per person), Iraq will require 9 million tons of wheat by 2020. Average wheat production is expected 
to drop by $12.5 \%$ by 2020 as a result of low precipitation and rising temperatures. $40 \%$ of the Iraqi daily dietary consumption is represented by wheat flour and its derivatives while the import enslavement in wheat is representing a real anxiety for food security.

On the economic front, the Investment Expenditure represents only 40\% (IQD 55.1 Trillion) of government expenditure in the 2013 Budget, which is the largest ever in Iraq. Investment in Oil and Electricity amounts to over $43 \%$ of the investment expenditure. The government budgeted revenues amount to IQD 119.3 Trillion, $93 \%$ of which from oil. The increase in oil revenues, made it possible to cover the government's operating expenditure (Joint Analysis Policy Unit-JAPU, 2013). The heavy dependence on oil resulted in a fragile budget to oil shocks, and government going through complementary budgeting, and extreme delays in investment project execution. In spite of the increase in oil production and revenues, oil by itself is not enough to cover up the budget deficit and have a say to a financial flexible Iraq; financial reserves in Iraq can cover up government operating expenditure for less than a year. In order to improve Iraq financial resilience and reserves in the short run, Iraq needs, in addition to its plan to increase oil revenues, to increase non-oil revenues (which are stable, around IQD 7 Trillion, since 2008), and to rationalize operating expenditure (Iraq has one of the largest public sectors relative to population). In the long run, revenue diversification goes hand in hand with diversification of the economy and expansion of the private sector expenditure (Joint Analysis Policy Unit-JAPU, 2013).

\section{The Sustainable Neighborhood}

Sustainable Development is a concept that was confirmed at; the World Summit on Sustainable Development in Johannesburg, 2002. It has been widely accepted all over the world on local, regional, national and international levels. While "Happiness" serves as a major goal of the European spatial development, it is also with accordance and can be easily compared with the concept of sustainable development (UN-Iraq, 2013).

The spatial planning process for happiness and SD in Europe consists mainly of two stages, analysis and synthesis. In the analysis phase a mixture of indicators is used to estimate the status of development in a country or in a region. The synthesis phase corresponds to a spatial development policy which is formed following certain planning objectives. The Europeans use "Happiness" as an attractive indicator for the comparative analysis of spatial development policies, and as a planning objective (Trkulja, 2007).

The inherited destruction (environmentally, socially and economically) and the dangers of its exacerbation, requires a pilot project, namely; The Sustainable Neighborhood (SN), that would create a regional development-model which can be implemented on a district or locality, within the city of Baghdad. The SN-project includes a clear vision and firm message; the improvement of the surrounding environment and social relations based on the inhabitants' priorities and thus ensure their participation in sustaining the achievements of the project.

The SN-project progress toward its goal and objectives is monitored by a committee and continuously improved throughout all stages of implementation to completion, after which the sustainability of the project should be carried on by the community itself as a result of inheriting the values that justified the project.

\subsection{Expected Outputs}

1) Create a national model for sustainable community enriched with the principles of citizenship (rights and obligations), sharing risks and disaster management, cooperate in improving the environment, support the developmental achievements and contribute to their sustainability.

2) The community's comprehension and evaluation of the required executive institutions' services, and demanding those services as civil rights.

3) To motivate the state's institutions to adopt strategies to achieve sustainable communities.

\subsection{Management}

The project is managed through an executive committee which consists of experts and specialists in the field of sustainable development and urban planning at: universities, research institutes, service departments, local administrations, and civil society organizations.

The Committee is responsible for managing meetings and workshops with the partners and beneficiaries to achieve the goals of the project in addition to the formation of community-based groups to participate in the im- 
plementation stages.

\subsection{Means of Implementation}

1) Presenting the project for discussion at the level of the UN-organizations and receive their opinions to enrich the project plan and attract their attention to the need for their support through all the UN organizations.

2) Discuss the idea behind the project and its importance, with Baghdad Provincial Council to get their approval to provide the locality(s) after setting certain criteria. Selecting two "neighborhoods" would enrich the project as they could compete for achieving better results.

3) Coordination with local councils to choose two implementation areas for the project and to proceed with their role during the implementation through; suggesting advice and provide support and assistance, but not making decisions.

4) The SN-Project locations are selected on the basis of their socio-economic similarity and social, ethnic and religious diversity.

5) Discussing the project idea with the governmental services' institutions for the purpose of directing their attention to the need to work within the framework of sustainable communities and seek opportunities for their contribution and support.

6) Making use of the schools in clarifying the idea of the project and motivate the community to support the Project for the sake of their livelihood and future generations.

7) Using the influential groups (religious and selective personnel) in urging the community to support the project and its sustainability.

\subsection{Mechanisms of Implementation}

1) Preparation of socio-economic assessment for the project selected locations in order to develop an action plan, which depends on; the duration of the Project plan and the available resources.

2) Sensing the environmental and services' priorities of the community through a questionnaire distributed to school students to deliver to their families after an educational meeting with the students on the concepts of SD and its importance.

3) Holding a series of meetings with residents to discuss their preferences and explaining the available capacities of the executive institutions and getting lessons on how to deal or adapt with some of these priorities.

4) The action plans depend mainly on the chosen localities and the community's preferences, which determine the future activities of the project in order to ensure the sustainability of resources and support of the community.

\subsection{Project's Sustainability}

1) Community's convincement that the project contributes to improving their livelihood which would depend on the level of their participation to achieve its goals.

2) Enlightening the related institutions of the SD concept and SN and the demand for their continuing service in developing the community.

3) Investing the understanding of SD and SN concept and applications, to develop the capacities of the services' institution.

4) International partners to further support the project as it represents part of their achievement on CSR at global level.

\subsection{Further Expectations}

Upon developing the project, the sustainability factors should be extended to encompass several elements of the natural capital (Sustainable consumption \& production), and the human and social capital (sharing responsibilities and commitments) and also financial/built capital (conserving in e and urban features).

\subsection{Role of Media}

The Media support is essential for the project promotion, encouraging the state institutions to support the Project, developing capacities on SD and SN amongst media institutions and personnel. 
The sustainability of the project demands the Media as well to focus on the challenges of project continuity in relation to the institutional support and community participation.

\subsection{Potential Risk}

Based on the current security situation, the risk potential is always available for any project. Still, for this project the potential risk might be at the lowest level as it is meant to serve the community and thus, will be protected by them.

\section{Discussion}

The current high natural resources' consumption rates accompanied with the unilateral economy in Iraq demands that the development trajectories should be readjusted and well planned to ensure a closed recycling system of revenues into sustainable development accomplishments. Any waste of such transition would simply mean; wasting the ephemeral natural resources, demolishing its revenues and turn the community's being into despair and frustration which eventually scratching their citizenship and loyalty to their country.

Spatial development policy is a strategic planning process that has objectives to be implemented and monitored. The objectives are in accordance with the participatory vision of development which corresponds to the desired future for the population living on the territory for which development plan is being set (Trkulja, 2007).

The package of measures and legislation, guaranteeing the achievement of the development goals, are the most important indicators of good governance at the national and local levels, as they (MDGs) represent the framework of what would bring prosperity to all the society sectors of both, current and future generations (Figure 1).

The progress in the developmental achievements of the society, in the light of the eight MDG goals (and the SDGs after 2015), requires a triple partnership; close cooperation and coordination between; government (decision makers), the whole society (civil society organizations) and the specialized institutions. Also, the fact that the MDGs we seek to achieve are diverse and also interrelated, demand internal coordination within each partner. Simply saying, none of the MDGs could be achieved unless all MDGs progress simultaneously (Figure 2).

Responsible governments seek to build "Sustainable Communities", as they represent the integrated model of development and represent the modern example of reliable, SD-states. Such communities (SC) are characterized by their positive interaction among society sectors, and also between them and the public services' institutions, seeking to achieve prosperity at the present and future.

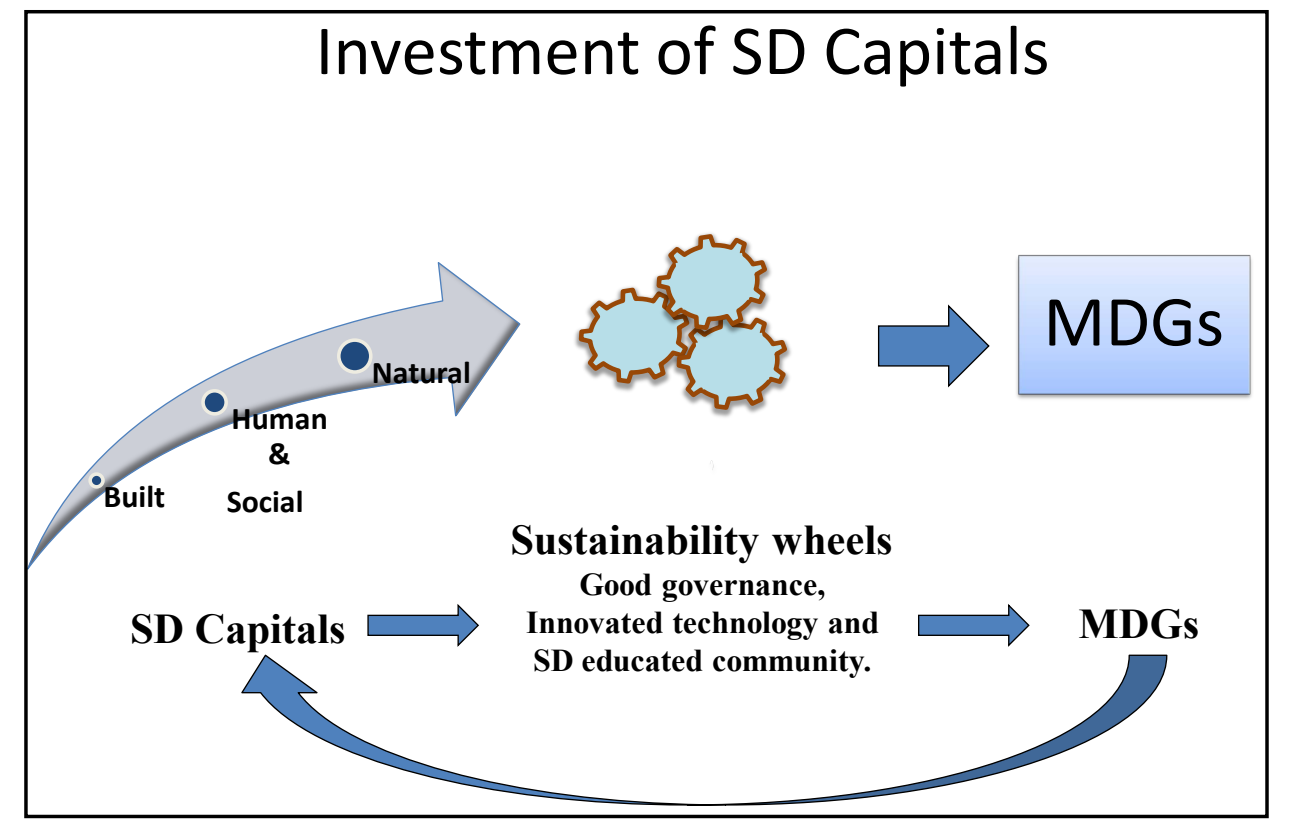

Figure 1. Investment of sustainable development capitals. 


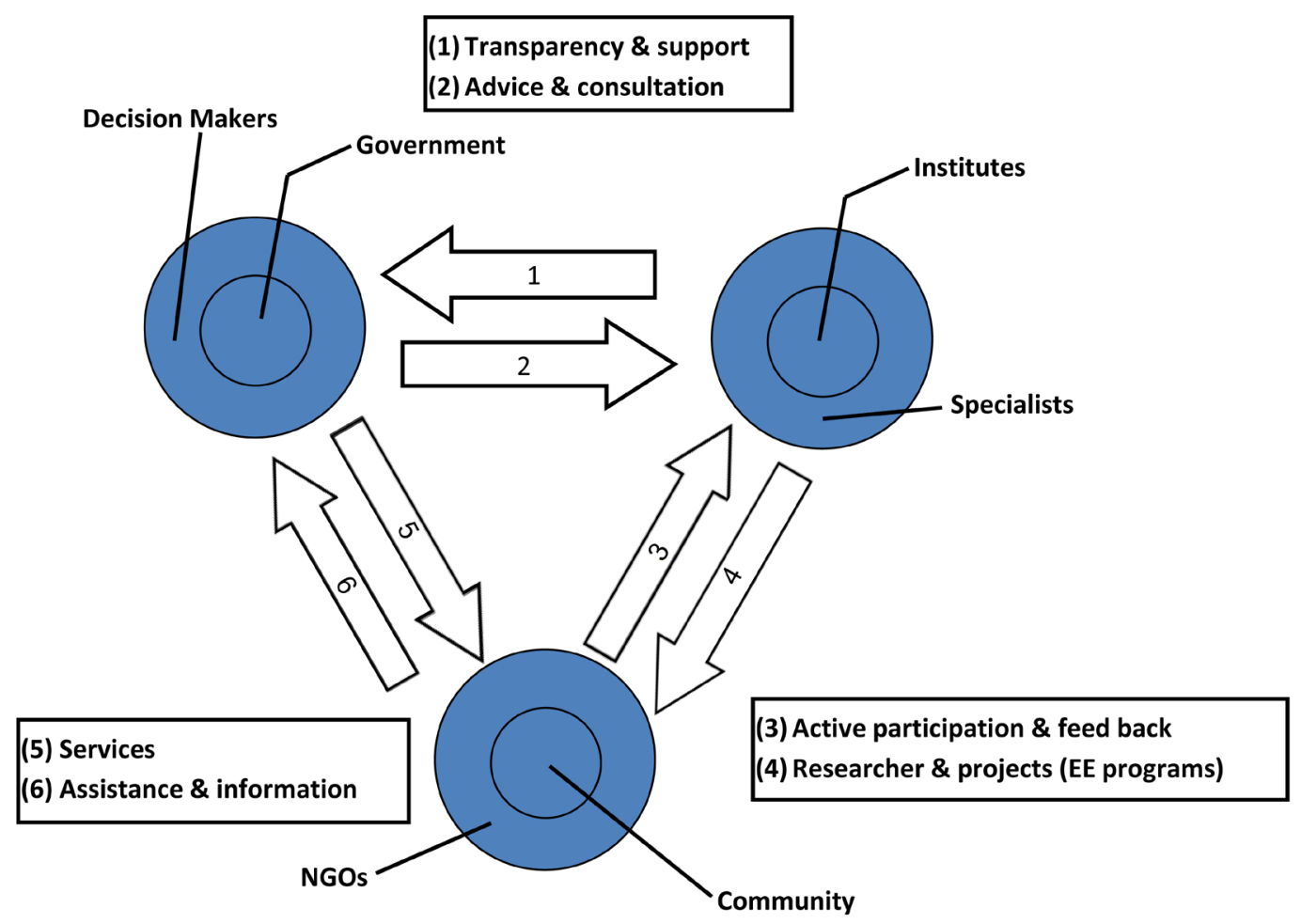

Figure 2. The triple partnership.

The sheer scale of the inherited destruction, to the environment and the economy in Iraq has cast a shadow over the Iraqi citizen demanding the need for "investments for sustainable development". The stakeholders in the authority of developmental change (government, community and specialized institutions) are invited to, jointly and constructively cooperate, in order to diagnose the challenges, develop solutions, and contribute to resolving collective. The progress towards SD would not be possible without that level of cooperation and accordingly need the adoption of "creating a model"; it serves as a perfect exhibition to apply what can be emulated regionally or nationally and also developed and sustained by the government and specialists.

The idea of "creating a model" is certainly useful in cases similar to the Iraqi conditions as it, in addition to solving a problem at a spatial level, could serve as; a hope to others, on-site learning opportunity for students, a research laboratory for professionals, and a success story for the decision-makers and participating institutions.

\section{Conclusion}

Iraq is failing to translate the revenues to development. The community is suffering from poor services and claiming their right to improve living standards from the government, while the government is arguing that the people are careless and not cooperating with the services' departments. The situation is a clear case of exploiting the sole revenue resource (oil) without any developmental gains. The arising societal demands for services and continuous failure of the government to fulfill its constitutional commitments in serving the people are endangering the already fragile peace and widening the gap between the Iraqi people and the institutional bodies (government, parliament and judicial system). The fears and uncertainty shadow the scene and unless the developmental trajectories are diverted to serve the community and ensure their wellbeing, Iraq's survival as a country is at imminent danger.

Sustainable development main goal is to provide societal happiness based on eco-efficient economy, mainly related to the patterns of consumption and production. Unsustainable life styles exploit natural resources without gaining any developmental outcome ending with poorness and misery.

Recognizing the severe challenges of sustainable development and knowing that Corruption, Good Governance and Conflicts are usually integrated elements affecting societal livelihood, and a spatial SD-Model could be an ideal solution to reveal the real reasons after the poor public services despite the high annual expenditure 
rates.

The Sustainable Neighborhood is a project designed to ensure the best possible public services for the residents of a defined locality in Baghdad City as a result of collaboration between the services' department (government) and the community. The project is supervised by experts/specialists in strategic planning and sustainable development, and directly managed by selected/elected community representatives. Although the project is still not activated, there are good indications that the government of Iraq might support the idea and sponsor the project.

The SN project is expected to guide the future patterns of delivering public services, preserving resources/ sustainable consumption, and community cooperating with the government.

\section{References}

Al-Anbagy, A., Aljebouri, H., \& Alshalal, M. (2011). Analysis of the Budget (2011) in Iraq and the Extent of Their Consistency with the National Development Plan for the Years 2010-2014, Introduction to the Study of the Advisers in the Province of Babylon (in Arabic).

Al-Ansari, N. A. (2013). Management of Water Resources in Iraq: Perspectives and Prognoses. Journal of Engineering, 5, 667-668. http://dx.doi.org/10.4236/eng.2013.58080

Al-Ansari, N. A., \& Knutsson, S. (2011). Toward Prudent Management of Water Resources in Iraq. Journal of Advanced Science and Engineering Research, 1, 53-67.

Al-Ansari, N. A., Ali, A. A., \& Knutsson, S. (2014). Present Conditions and Future Challenges of Water Resources Problems in Iraq. Journal of Water Resources and Protection, 6, 1066-1098. http://dx.doi.org/10.4236/jwarp.2014.612102

Al-Ansari, N. A., Ali, A. A., \& Knutsson, S. (2015). Iraq Water Resources Planning: Perspectives and Prognoses. In ICCCE 2015 13th International Conference on Civil and Construction Engineering (pp. 2097-2108). Jeddah: World Academy of Science, Engineering and Technology.

Al-Khateeb, M. (2010). The Participation of High Education in the Instantaneous Preparation of Sustainable Development Human Resources. In 5th International Forum on Engineering Education. Paper No. ED-4-103, Paperno: UAE.

Allen, R., \& Slotterback, C. S. (2011). A Vision for Inclusive, Sustainable Communities: Strategies for Engaging Increasingly Diverse Residents. Minnesota: University of Minnesota.

http://citeseerx.ist.psu.edu/viewdoc/download;jsessionid=1FE0E6DB7FB829066544550F69A2D25A?doi=10.1.1.396.723 4\&rep=rep1\&type $=$ pdf

Allen, R. (2013). A Vision for Inclusive, Sustainable Communities: Strategies for Engaging Increasingly Diverse Residents. University of Minnesota, Carissa, Schively Slotterback, Provider, Citeseer, 2013.

http://citeseerx.ist.psu.edu/viewdoc/download;jsessionid=1FE0E6DB7FB829066544550F69A2D25A?doi=10.1.1.396.723 $\underline{4 \& \mathrm{rep}=\mathrm{rep} 1 \& \text { type }=\mathrm{pdf}}$

Al-Monitor (2014). Iraq. Last Accessed September, 2015.

http://www.al-monitor.com/pulse/security/2014/08/kirkuk-kurdistan-region-oil-economy-iraq-government.html

Beta (2014). US Energy Information Administration (EIA). http://www.eia.gov/countries/country-data.cfm?fips=IZ

Brundtland, G. H. (1987). Our Common Future, Report of the World Commission on Environment and Development. http://www.un-documents.net/our-common-future.pdf

Cordesman, A. H., \& Khazai, S. (2014). Iraq in Crisis, Center for Strategies and International Studies. http://csis.org/publication/iraq-crisis-1

Dictionary.com (2015). Iraq. http://dictionary.reference.com/browse/iraqi

Environmental Performance Index (2005). Country profile, Iraq. http://www.infoplease.com/ipa/A0930889.html

Environmental Performance Index (2008). Country Profile, Iraq. http://www.yale.edu/epi/files/2008EPI Text.pdf

Environmental Performance Index (2010). Country Profile, Iraq. http://epi.yale.edu/files/2010_epi_summary_for_policymakers.pdf

Environmental Performance Index (2014). Country Profile, Iraq. http://www.fao.org/docrep/005/y4473e/y4473e08.htm

ESCWA (Economic and Social Commission for Western Asia) (2013a). SDG Priority Conceptual Issues: Towards an Arab Approach for the Sustainable Development Goals. Tunisia: ESCWA.

https://sustainabledevelopment.un.org/content/documents/2973E_ESCWA_SDPD_13 TP-8_E.pdf

ESCWA (Economic and Social Commission for Western Asia) (2013b). Inventory of Shared Water Resources in Western Asia (626 p). Beirut: Salim Dabbous Printing Co.

FAO (2010). Review of Water Resources Statistics by Country, Iraq. http://www.fao.org/countryprofiles/index/en/?iso3=IRQ 
IAU, UN (2012). Sustainable Development, Green Economy and Oil and Gas in Iraq. http://iq.one.un.org/documents/469/Sustaiblable\%20Development $\% 20-\% 20$ English.pdf

JAPU (2014). Integrated Drought Risk Management-DRM (p. 101). National Framework for Iraq Analysis Report. http://www.unesco.org/new/fileadmin/MULTIMEDIA/FIELD/Iraq/pdf/Publications/DRM.pdf

Joint Analysis Policy Unit (JAPU) (2013). Iraq Budget 2013. Background Paper, JAPU, UN. http://www.iau-iraq.org/documents/1841/Iraq\%20Budget.pdf

Mikail, B. (2013). Refugees in the MENA Region: What Geopolitical Consequences? Policy Brief, the Middle East and North Africa: Fride. http://fride.org/publication/1148/refugees-in-the-mena-region:-what-geopolitical-consequences

Natural Resource Governance Institute (2015). Middle East and North Africa. http://www.resourcegovernance.org/countries/middle-east-and-north-africa/iraq/transparency-snapshot

Relief Web (2012). Food Security, Living Conditions and Social Transfers in Iraq. http://reliefweb.int/report/iraq/food-security-living-conditions-and-social-transfers-iraq

Transparency International (2011). Corruption Perception Index 2010. https://www.transparency.org/cpi2011

Transparency International (2011). Corruption Perception Index 2011. https://www.transparency.org/cpi2011

Trkulja, S. (2007). Happiness as Indicator and Planning Objective for the Spatial Development Policy. In 3rd International Conference on Gross National Happiness (10 p.). Bangkok: Chulalongkorn University.

UN (2013a). A New Global Partnership: Eradicate Poverty and Transform Economies through Sustainable Development. The Report of the High-Level Panel of Eminent Persons on the Post-2015 Development Agenda, Executive Summary. http://www.un.org/sg/management/pdf/HLP P2015 Report.pdf

UN (2013b). Water in Iraq Factsheet. http://www.iau-iraq.org/documents/1866/Water-Factsheet.pdf

UN (2013c). Sand and Dust Storm Fact Sheets. Joint Analysis and Policy Unit (JAPU). http://reliefweb.int/report/iraq/sand-and-dust-storm-fact-sheet

UN Document (1987). Our Common Future, from One Earth to One World. From A/42/427, Our Common Future: Report of the World Commission on Environment and Development, Gathering a Body of Global Agreements.

UNDP (2015). Eradicate Extreme Hunger and Poverty, Where Are We? Iraq Country Office: United Nations Development Program. http://www.iq.undp.org/content/iraq/en/home/post-2015/mdgoverview/overview/mdg1.html

UN-Iraq (2013). World Environment Day 2013. Factsheet. https://www.gov.uk/government/statistics/world-environment-day-factsheet-2013

University of Technology Environmental Research Center (2013). First Environmental Conference 29-30 December, 2013. http://www.uotechnology.edu.iq/environmental/index.htm

Wehrey, F. (2014) Sectarian Politics in the Gulf: From the Iraq War to the Arab Uprisings. Columbia: Columbia University Press. http://carnegieendowment.org/2013/12/17/sectarian-politics-in-gulf-from-iraq-war-to-arab-uprisings/gw4t

WHO (2011). “We Came with Nothing, We Have Nothing”: Thousands Flee Fallujah as Fighting Intensifies. Country Cooperation Strategy at a Glance. http://www.emro.who.int/iraq

\section{Scientific Research Publishing}

\section{Submit or recommend next manuscript to SCIRP and we will provide best service for you:}

Accepting pre-submission inquiries through Email, Facebook, LinkedIn, Twitter, etc.

A wide selection of journals (inclusive of 9 subjects, more than 200 journals)

Providing 24-hour high-quality service

User-friendly online submission system

Fair and swift peer-review system

Efficient typesetting and proofreading procedure

Display of the result of downloads and visits, as well as the number of cited articles

Maximum dissemination of your research work

Submit your manuscript at: http://papersubmission.scirp.org/ 